\title{
31
}

\section{THEATER SPECIAL OPERATIONS COMMAND}

\section{The operational employment of U.S. Special Operations Forces}

\section{Charles T. Cleveland and Liam Collins}

The U.S. Department of Defense divides the world into six geographical areas, with geographic combatant commanders (GCCs) responsible for nearly all missions within their assigned geographical area of responsibility. ${ }^{1}$ Central Command's area of responsibility includes 20 countries in the Middle East, Central and South Asia, and surrounding waterways; Africa Command includes all 54 African countries, with the exception of Egypt, and surrounding waterways; European Command includes Europe, Russia, and surrounding waterways; Northern Command includes the United States, Canada, Mexico, and surrounding waterways; Indo-Pacific Command includes 36 states in Asia and the Pacific Ocean and much of the Indian and Pacific Oceans; and Southern Command includes 31 countries in Latin and South America and surrounding waterways.

Subordinate to each GCC is a service component command for each service, including special operations. For example, Central Command includes U.S. Army Central, U.S. Naval Forces Central Command, U.S. Air Forces Central, Marine Corps Forces Central Command, and Special Operations Command Central (SOCCENT). These service component commands vary in size and composition but have essentially the same purpose: they execute the service's statutory requirements to provide administration and logistics to all service forces in the geographic combatant command. They may also conduct operations with forces that they receive when directed by the combatant commander. $^{2}$

In peacetime, these subordinate service headquarters are primarily administrative headquarters that command and control forces on exercise or conducting joint training events. They can, however, be augmented and tasked to serve as joint (multi-service) or combined (multinational) warfighting commands when directed by the combatant commander. ${ }^{3}$ Army Central, for example, became the Combined/Joint Land Component Command headquarters for the 2003 invasion of Iraq.

The Theater Special Operations Command (TSOC) performs a similar function for all service Special Operations Forces (SOF), with the exception of those assigned to the Joint Special Operations Command. Today's TSOCs have become an indispensable capability for a wide variety of missions ranging from combat operations against emerging threats to supporting humanitarian assistance missions. This chapter examines the history of the TSOCs and then provides two campaign vignettes to illustrate how they plan and execute operations in support of the GCC. 


\section{Establishing the TSOCs}

The TSOC is a critical component in the country's special operations arsenal. It is, however, a command construct that has had to fight for its existence from the start. The government is notorious for resisting new constructs, and this was especially true for the TSOCs.

Regionally oriented and largely independent from conventional forces, special operations have been a part of the American way of war since the revolution. Francis Marion, the "Swamp Fox," and his guerrilla campaign against the British in South Carolina is an early example. ${ }^{4}$ General Philip Sheridan's campaign against infrastructure in the Shenandoah Valley and the Army's experience in the Indian wars in the American West in the last half of the 19th century are others. In World War II, the Office of Strategic Services' work with the French resistance in Europe or its campaign in Burma are further examples. It can be argued that command and control of these efforts were the predecessors of today's TSOCs.

It was fighting against the Soviet and Chinese communist-supported insurgencies of the Cold War, however, where the United States saw the limits of conventional forces. The communists sought to weaken and discredit the ideals of free societies and the democratic system of government and to convince vulnerable populations that it was worth fighting for a communist way of governing. It was in the face of this persistent threat, often taking place below the threshold of conventional war, that the need to orchestrate special operations and irregular warfare activities became critical.

President John F. Kennedy recognized this new type of war in his Inaugural Address in 1961, and the Army became the leader for counterinsurgency within the U.S. Defense Department. ${ }^{5}$ It created the Institute for Military Assistance to promote learning on this new way of war. The Army created other organizations to fight the insurgent threat, and it expanded Special Forces, civil affairs, and psychological operations capabilities. ${ }^{6}$

The most radical and arguably best example of enlightened thinking was the U.S. Army Special Action Forces. The Special Action Forces was a brigade-sized element that consisted of regionally oriented Special Forces, military police, engineer, psychological operations, civil affairs, and medical units, primarily focused on counterinsurgency. The 8th Special Action Forces operated from Ft. Gulick, Panama, from 1963-1972. ${ }^{7}$ Coming out of Vietnam, the U.S. Army's priority shifted to conventional warfighting to counter the Soviet threat in Europe, and the Army largely purged counterinsurgency doctrine and training until Operations Enduring Freedom and Iraqi Freedom, more than a quarter century later. ${ }^{8}$

While conventional forces committed themselves to the plains of Europe and the Korean Peninsula, the need for regionally attuned forces and headquarters reemerged in the 1980s with the return to fighting communist insurgencies in Latin America. At the same time, troubled missions in the early 1980s spurred Congress to enact the largest reorganization of the Department of Defense since the National Security Act of 1947. As part of this reform, Congress directed the establishment of special operations headquarters to better prepare for and conduct the nation's special operations missions and irregular warfare campaigns.

The first troubled mission occurred on April 24, 1980. After six months of planning and preparation, the United States initiated Operation Eagle Claw, a raid to rescue the 53 American hostages who had been held in the U.S. Embassy in Tehran following the 1979 Iranian Revolution. The mission, however, was aborted at Desert One, a rendezvous in the Iranian desert roughly 650 kilometers southeast of Tehran, due to an insufficient number of helicopters required to continue the mission.

As the force departed, a helicopter collided with one of the C-130 aircraft carrying fuel, igniting an explosion that destroyed both aircraft and killed eight military personnel. ${ }^{9}$ The underlying problem that contributed to the failure was an inability of the services to work together. ${ }^{10}$ The Holloway Commission analyzed 23 issues and considered 11 of them major, including "command and control" and "overall coordination of joint training." 11 
Attempts at structural reform started shortly thereafter with the Ronald Reagan administration. Noel Koch, deputy assistant secretary of defense for international security affairs, made growing special operations capability a priority. The first step, in 1980, was creating the Joint Special Operations Command to "specifically focus on counterterrorist operations." 12 Koch later established a Special Operations Policy Advisory Group that included retired Admiral James Holloway. He also convinced Deputy Secretary of Defense Paul Thayer to sign a policy directive on October 3, 1983, which stated that "U.S. national security required the maintenance of special operations forces" and directed the services to complete several steps. ${ }^{13}$

An immediate effect of the "Thayer memorandum" was the establishment of the Joint Special Operations Agency within the Joint Staff. The Joint Staff and the services largely opposed the directive, and as a result, the agency was weak and generally ineffective. ${ }^{14}$

The Joint Special Operations Agency directed the GCCs to establish a TSOC within their operations directorates from their existing manpower authorizations. The creation of overhead in the form of a headquarters is usually contentious. In this case, it was doubly so. Pushback came from within the GCC staff, a fractious special operations community, and from the services themselves. Each GCC operations directorate, with the exception of European Command, lost 23 authorizations, 18 officers and five enlisted, to create the TSOC. European Command simply rebranded its existing Special Operations Task ForceEurope as its new Special Operations Command Europe. The Joint Special Operations Agency directive was not welcomed.

Furthermore, the U.S. Army had significant factions within its senior ranks who did not support the creation of a new special operations headquarters. Even though the new TSOCs were to address missions viewed as low priorities, the Army viewed any shift of mission to another organization as a budget threat and an unnecessary diversion of assets.

Only weeks after Thayer signed the policy directive, the United States invaded Grenada during Operation Urgent Fury. Fearing for the safety of the roughly 1,000 Americans in Grenada-many of whom were students at the island's medical school-President Reagan ordered several thousand troops to invade and secure their safety. ${ }^{15}$ The operation was deemed a success, but at the same time demonstrated the structural dysfunctions within the military.

The most glaring shortcoming was a "nearly crippling" lack of communications between the services. This problem became well known after an officer used a pay phone to call his headquarters in the United States in an attempt to get fire support from a naval ship that he could not communicate with but could see visually. In other cases, bureaucratic procedures presented obstacles. On the first day of the invasion, "a Navy commander disregarded orders that would have prevented him from refueling Army helicopters that were evacuating wounded soldiers 'because funding arrangements had not been worked out in Washington.", 16 A Senate study concluded that "URGENT FURY demonstrated that there are major deficiencies in the ability of the services to work jointly when deployed rapidly." 17

The terrorist bombings of the Marine Barracks in Lebanon the same month highlighted issues with the authorities and responsibilities of the combatant commanders. U.S. European Command had limited authority to direct service components within its area of responsibility. General William Smith, the European Command deputy, remarked,

I really felt the Marines didn't work directly for me. On paper, they were under our command, but in reality, they worked for the commander in chief, U.S. Naval Forces Europe, our naval component. They had their own operational and administrative command lines. . . We could advise, of course, but no more. ${ }^{18}$

These missions highlighted the weaknesses of the GCCs and the inability of the military to work jointly and provide effective military advice to its elected officials. 
As a result, Congress passed the Goldwater-Nichols Department of Defense Reorganization Act, signed into law by President Reagan on October 1, 1986. The law contained a number of objectives. For special operations, the law, as modified by the Nunn-Cohen Amendment, directed that segregated service special operations capacities - such as service funding for training and special operations peculiar equipment - be consolidated and created U.S. Special Operations Command (SOCOM) ${ }^{19}$ SOCOM was created from the U.S. Readiness Command, with General Jim Lindsay, an early member of the 10th Special Forces Group, as its first commander. ${ }^{20}$

SOCOM's purpose was to ensure investment in needed special operations capabilities, and this logically led to support for a similar component command for this newly assembled service-like, special operations capability. In fact, it was SOCOM's immediate and unpopular predecessor, the Joint Special Operations Agency, that had directed each of the GCCs to stand-up the TSOCs.

One of the main fallouts of this sequence of events was that the TSOCs were not originally included in SOCOM's constellation of assets, denying them a four-star special operations patron and its funding stream, leaving them organizationally orphaned. It would take nearly 30 years for the situation to change. ${ }^{21}$

The GCC received funds from the services, and as a subordinate command within the GCC, the TSOCs were required to do the same. Since SOCOM did not own the TSOCs, it could not provide funding as it did for other SOF units; that responsibility fell to the services. Thus, the level of service support depended largely on the personalities involved and the GCC support to their TSOC. SOCOM was not compelled to support the TSOC until 2014, when the secretary of defense assigned SOCOM combatant command of each TSOC. ${ }^{22}$ This meant that SOCOM finally had the responsibility to "organize, train, and equip TSOCs as it previously had for all assigned SOF units." 23

Also unique is the role that the TSOC commander plays as either an advisor to the GCC for special operations matters or as a sub-unified commander. Few special operations officers serve on GCC staffs, leaving these staffs deficient in planning and employing special operations capabilities. They have to rely on the TSOC to ensure these highly trained, strategic assets are appropriately employed.

The TSOCs share many characteristics with their service counterparts, but they also have several unique roles that reflect the fact that they are a joint headquarters, manned by special operations and support officers and enlisted personnel from all services. In simple terms, the TSOC has administrative control, or responsibility, for personnel actions, such as accountability, efficiency reports, good order and discipline issues, and SOF common requirements. ${ }^{24}$

While the SOCOM commander may "exercise command of selected special operations missions if directed to do so by the president or the secretary of defense," special operations are generally "conducted under the command of the [GCC]." ${ }^{25}$ Thus, whether special operations fall under the command of SOCOM or the GCC, the TSOC plays a critical role in the employment of nearly all SOF employed worldwide, either directly or through a subordinate task force.

Exercising operational control for special operations gives the TSOC a uniquely powerful and influential role. SOF capabilities range from the ability to conduct strike operations on short notice to special warfare operations, such as developing indigenous force options for local and regional challenges over the long term when large-scale U.S. military options are not feasible or desirable. The two parts of American SOF are not mutually exclusive capabilities; however, they do require very different formations and skill sets, and each has its own risks and payoffs. ${ }^{26}$

For each GCC, their TSOC develops campaigns (for example, plans that sequence operations of varying types such as raids, lethal strikes, partnered operations, capacity building, intelligence, psychological operations, or civil affairs missions) over time and in space to achieve GCC objectives. The TSOC is the primary author of SOF campaigns in the GCC's area of responsibility. ${ }^{27}$

To propose pertinent and supportable campaigns, the TSOC staff must study documents from the White House, National Security Council, Department of Defense, and Joint Staff, as well as those of the GCC and U.S. Embassy country plans. It views each through a "special operations lens," determining 
opportunities and requirements for which special operations are suited, and then seeks support for the development of a SOF campaign. It is important to note that no other command or staff element in the GCC is capable of this analysis. Furthermore, as of yet, there is no doctrine that prescribes what constitutes a SOF campaign, let alone one that exists below the threshold of traditional war.

Each campaign is different, often requiring nuance and understanding that uniquely resides within the TSOC. After a normally intense interaction with the GCC and SOCOM staffs to gain support for the proposed campaign, the TSOC commander seeks the GCC's approval. With GCC approval comes the authorities required or the support necessary to gain those authorities and resources from SOCOM and the Joint Staff to execute the plan.

The nature of each campaign varies based on the policy objectives: for example, counterdrug, counterinsurgency, counterterrorism, civil affairs, foreign internal defense, or, as is often the case, a combination of multiple activities. In all cases, the TSOC must maintain a campaign perspective while maintaining a crisis response capability to react to emergencies of all kinds-from earthquake relief, to noncombatant evacuations, to hostage rescue and recovery. ${ }^{28}$

SOF campaign development has the benefit of providing purpose, intent, and direction to subordinate elements, other components, Joint Task Forces, and embassy country teams. The process of developing SOF campaigns allows for detailed discussions with interagency partners in the affected region and countries, and it often requires coordination with Department of State Regional Bureaus, the Central Intelligence Agency, the U.S. Agency for International Development, and other players as required.

The Drug Enforcement Administration, for example, is a significant partner in U.S. Special Operations Command South's (SOCSOUTH) operations in the Andean Ridge of South America. A SOF campaign plan identifies needed forces, authorities, and support requirements. ${ }^{29}$ Once approved, it serves as a common point of departure for the various agencies impacted or supporting the campaign.

Last, SOF campaign doctrine and theory remains a developing and still controversial field. Work is underway at the U.S. Army Special Operations Command and at the John F. Kennedy Special Warfare Center and School at Fort Bragg, North Carolina. As the United States comes out of two of its longest wars in Afghanistan and Iraq, with special operations having played a significant role in each, these two commands have recognized the need to ensure they remain the subject matter experts in the application of special operations.

\section{TSOC campaign vignettes}

The following vignettes are prime examples of SOF campaigns, highlighting their multifaceted and strategic nature. Both were set in uncertain geopolitical situations and designed to provide options to policymakers should military operations become necessary. The TSOC's role was to develop, secure approval, resource, and ultimately execute long-term special warfare campaigns, such as foreign internal defense or unconventional warfare. These campaigns had, at their core, building and maintaining relationships with partner nations and indigenous groups to ensure their ability to secure or help secure objectives in the region.

In some cases, the relationship building was not necessarily directed at a specific objective but to set conditions for policy options using U.S. supported indigenous military or paramilitary operations. It is work that by necessity is long term, uncertain, and often without immediate payback.

\section{Operation Willing Spirit and the recovery of three American hostages (2003-2008)}

During a routine counternarcotics mission on February 13, 2003, Tommy Janis was at the controls of a single-engine Cessna Grand Caravan. Janis worked for Northrop Grumman on a contract to fly aerial 
surveillance missions for U.S. Southern Command (SOUTHCOM) in support of Plan Colombia. Three other Northrop Grumman contractors-Tom Howes, Marc Gonsalves, and Keith Stansell- joined Janis on the mission, as well as an intelligence sergeant from the Colombian Army, Sergeant Luis Alcides Cruz. ${ }^{30}$

When the plane's lone engine failed at 17,000 feet, Janis' only option was an emergency landing in the dense mountainous jungle. Surprisingly, he was able to crash-land the Cessna on a "postage-stamp-sized" clearing in the jungle, with all five escaping without major injury. Unfortunately, they landed in a Revolutionary Armed Forces of Colombia (FARC) stronghold, and shortly after landing, 50-60 heavily armed FARC soldiers captured them. For whatever reason, the FARC rebels separated Janis and Cruz from the rest of the crew and killed them "execution-style" near the wreckage. ${ }^{31}$

Working with Ambassador Anne Patterson, Brigadier General Remo Butler, the SOCSOUTH commander, made their recovery his top priority. The difficulty of the terrain and lack of immediately available resources made an immediate recovery effort impossible. Stansell had been in constant communication with Ed Trinidad, a member of the Tactical Analysis Team at the U.S. Embassy, during the four-minute descent. He relayed his position throughout the descent, but the FARC seized the crew before a rescue mission could be launched to the remote location. ${ }^{32}$

As the opportunity faded, so did the support for SOCSOUTH to maintain a forward presence dedicated to their recovery. It would take more than two years before the U.S. Embassy would have another opportunity to locate the hostages and consider a rescue attempt. As is often the case, fortune played a role.

In July 2005, a mobile training team of seasoned SOCSOUTH staff officers was training their counterparts in the Colombian Special Operations Command on contingency operations planning when the U.S. Embassy Intelligence Fusion Center determined that a key piece of intelligence could be exploited to possibly determine the precise location of the American hostages.

While intelligence operations ramped up, the SOCSOUTH planners realized that they lacked the necessary operational capability to act on any time-sensitive intelligence to conduct a rescue attempt. The SOCSOUTH commander presented his assessment to U.S. Ambassador Bill Wood and SOUTHCOM Commander General Bantz Craddock, and he recommended that SOCSOUTH be tasked with working with their Colombian counterparts to create a campaign to develop options for a military rescue. ${ }^{33}$

As a result, SOCSOUTH established SOC-Forward Colombia, a small headquarters with a staff of 8 to 10 SOF staff officers under the command of either a U.S. Army Special Forces colonel or U.S. Navy SEAL captain. The team worked as a supported command within the embassy, taking orders from the Florida-based SOCSOUTH commander but under instructions to comply with all guidance from the ambassador. The SOCSOUTH commander periodically deployed to Colombia to oversee capacity building and planning and to take charge of the SOC-forward when intelligence presented potential rescue opportunities. ${ }^{34}$

Working with the Colombian Special Operations Command, the SOC-forward began what would become a three-year campaign to build joint capacity, plans, and, most importantly, mutual trust and confidence. The campaign, named Operation Willing Spirit, eventually developed Colombian Army, U.S.Colombian, and unilateral U.S. rescue plans. The August 2005 intelligence lead did not pan out, but the changes in U.S. and Colombian collaboration that resulted from it had lasting effects and ultimately contributed to the successful recovery of the hostages years later.

The next potential rescue opportunity occurred in the summer of 2006. Colombian Army intelligence identified the tentative location for the transfer of the hostages as they were to be moved from one FARC regional command to another. The U.S. and Colombia quickly mounted a partnered operation to interdict the FARC column, with the intent to recover the hostages.

The U.S. secretary of defense authorized six U.S. Special Forces soldiers from the 7th Special Forces Group and U.S. helicopters from the 3rd Battalion, 160th Special Operations Aviation Regiment, to join the Colombian rescue. While this partnered force successfully infiltrated undetected and observed a FARC security detachment, they did not get "eyes-on" the hostages. It was later learned that the force 
was 24 hours too late, and the FARC force they observed was likely the rear security for the column main body that escorted the hostages. ${ }^{35}$

In 2008, the combined efforts finally paid off with one of the most masterful deception operations in special operations history. In January 2008, Colombian and U.S. intelligence determined that the hostages were once again on the move. The FARC planned to move the hostages by boat and over ground through an area about the size of Maryland. The Colombian Army knew that terrain, and the FARC would be vulnerable because of poor support infrastructure.

Over the next two months, the Colombian Special Operations Command and SOC-forward deployed 15 reconnaissance teams: 10 Colombian special operations teams and 5 U.S.-Colombian partnered teams. In total, 32 special operators from the United States 19th and 7th Special Forces Groups and SEAL Team Four infiltrated on U.S. special operations helicopters in the attempt to locate the hostages. ${ }^{36}$ Other U.S. national military rescue capabilities also deployed in a supporting role to SOCSOUTH, with the understanding that if conditions were to allow for a rescue, roles would reverse. The TSOC owned the relationship, and until the mission became a unilateral U.S. rescue, the Colombian government would remain in charge.

More than 1,000 U.S. service members deployed to Colombia from January through March 2008. At this time, the U.S. government and the hostages' families received the first positive proof of life since their captivity began five years earlier. A Colombian reconnaissance team observing a FARC site on the Apoporas River reported "eyes-on" the Americans when they were led to the river to bathe. Unfortunately, as was routine, the FARC moved positions before a rescue operation could be mounted safely. ${ }^{37}$

To block the FARC hostage movement into the heavy jungle area, which served as the group's sanctuary, the Colombians mounted a raid and occupied a critical choke point at the urging of their U.S. counterparts. The action worked, forcing the FARC to return with the hostages to the more vulnerable location that had prompted their move in the first place. While an immediate rescue opportunity slipped away, U.S. confidence in Colombian leadership was never higher. Remarkably, the mission was not compromised; the raid operation had been launched under the guise of a joint training exercise as opposed to a hostage rescue mission.

The campaign expanded to include the Colombian conventional army to put additional pressure on the FARC element. Over the next three months, an elaborate deception operation took shape. Operation Jaque (Checkmate) involved Colombian intelligence and special operations, through a series of intelligence deceptions, hustling the FARC into passing 15 hostages-including the 3 Americans - to a group of Colombian special operators posing as members of a non-governmental aid organization. The ruse was to have the fake non-governmental organization transport the hostages via helicopter to the area where the FARC had wanted to move the hostages earlier in the year.

With a strong recommendation of support from the ambassador and the SOCSOUTH commander, SOUTHCOM Commander Admiral Jim Stavridis sanctioned Operation Jaque and obtained approval from the highest level of the U.S. government to conduct the operation. Stavridis believed the plan would require operational and organizational precision, as well as finesse, given the uncertainty of the hostages' location in the dense jungle. ${ }^{38}$ To support the operation, SOCSOUTH deployed its Special Forces Contingency Response Force from the 7th Special Forces Group as a quick reaction capability. ${ }^{39}$

On July 2, 2008, the FARC fell for the ruse, which had been initiated by a mole who had been planted within the group a year earlier. The FARC believed the mole was leading them to another FARC camp, but instead he led them into a trap. The ruse included Colombian troops disguised as aid workers, fellow guerrillas, and a cameraman and journalist from a fictitious pan-Latin American television station.

The FARC captors, along with their 15 hostages, boarded an Mi-17 helicopter for what they believed would be a short flight to rebel leader Alfonso Cano's camp. Instead, once the helicopter was airborne, the Colombian forces subdued the FARC rebels. ${ }^{40}$ The hostages were recovered without a single shot being fired. The three American hostages were finally free after 1,967 days in captivity. The rescued Americans 
served as guests of honor at the SOCSOUTH change of command in Homestead Air Force Base in south Florida less than one month later. ${ }^{41}$

The operation was a remarkable success, often compared to the U.S. raid in Pakistan that killed Usama bin Ladin in 2011. Yet this operation was significantly different. The Abbottabad raid was a unilateral raid by U.S. SOF. By contrast, Operation Jaque was largely a Colombian operation that was only possible because of the multi-decade investment by the United States to build Colombian capacity. ${ }^{42}$

U.S. Army Special Forces Major Russ Ames best summarized the success of this decades-long commitment when he remarked,

The highest praise for a [foreign internal defense] effort is when the host nation achieves a level of capability, that, when combined with their local knowledge and language, makes them more effective than [the United States] could ever hope to be. . . This is the holy grail of Special Forces work. ${ }^{43}$

\section{Lebanon (2008-present)}

There are few better examples of the long-term positive effects and the methodical development of options for policymakers and senior military leaders than SOCCENT's campaign to support the Lebanese Armed Forces. In 1976, Syrian troops entered Lebanon as part of an Arab peacekeeping force shortly after the Lebanese civil war broke out, but they soon transitioned from peacekeeper to occupier. They ultimately remained in Syria for 29 years, finally pulling out in $2005 .{ }^{44}$

Following Syria's withdrawal, the United States increased its assistance to Lebanon, providing $\$ 86$ million in fiscal year 2006, $\$ 843$ million in 2007 , and $\$ 73$ million in $2008 .{ }^{45}$ The large influx in 2007 was a result of the 2006 Lebanon War between Israel and Hezbollah, largely fought on Syrian soil. The war had highlighted the need for additional economic and military aid. ${ }^{46}$

In terms of military support, the United States had a near-continuous training program with Lebanese SOF and elite infantry units since the Syrian withdrawal. These units included the Lebanese Ranger Regiment, the 101st Airmobile Brigade, the Maritime Commando Regiment, and the Lebanese Commando Unit. By 2008, the training was routine, and the United States had developed strong relationships with the Lebanese Armed Forces at the tactical level. ${ }^{47}$

Yet the seizure of large swaths of western Beirut by Hezbollah fighters in May 2008 showed that much work was still needed for the Lebanese Armed Forces. ${ }^{48}$ As a result, SOCCENT reorganized its programs in Lebanon to accomplish three goals. The first was to posture U.S. forces in the region to contest the primacy of Lebanese Hezbollah, which served as an Iranian proxy group.

The second was to professionalize Lebanese SOF so they could conduct raids and, at the request of the U.S. ambassador, assist Lebanese SOF in the training of Lebanese Armed Forces conventional units, particularly the Intervention Brigades stationed south of the Letani River in southern Lebanon. It was important to show progress on United Nations Security Council Resolution 1701, which called for the cessation of all hostilities following the 2006 Lebanon War. It required Israel to withdraw from Lebanon, the disarmament of all armed groups (implying Hezbollah), and no armed foreign forces in Lebanon without the consent of the government. ${ }^{49}$

Yet Hezbollah had failed to disarm and still posed a significant threat to the government. Hezbollah, in effect, controlled parts of Lebanon..$^{50}$ It was important to build the Lebanese Armed Forces' capacity to replace Hezbollah as the guarantors of Lebanese security against external threats.

The third goal was to develop an enduring partner-building relationship with the Lebanese Armed Forces so that they could quickly conduct combined or joint operations against a growing terrorist threat emanating from Syria or the Bashar al-Assad regime. The United States sought to build Lebanese capacity to prevent another foreign invasion. 
Patterning from SOCSOUTH's success earlier in the year in Colombia, SOCCENT obtained approval to place two staff officers at the U.S. Embassy to develop and execute a SOF campaign on behalf of the ambassador and the CENTCOM commander. Although this new element initially authorized only two persons, it was designated a SOC-forward and was composed of a commander (a special operations colonel) and an operations officer from the SOCCENT staff. While small in number, they could task dedicated elements operating in direct support of their mission back at SOCCENT headquarters in Tampa, so its capability far exceeded the two officers in Beirut. Creating the small headquarters element (SOC-forward) greatly increased SOCCENT's ability to increase partner capability and provide options for the United States in future crises. It expanded engagement and influence up to the chief of defense level by providing the embassy a third senior officer in Beirut, supplementing the defense attaché and the security assistance officer. As a special operations officer, he provided expertise that the embassy lacked. He quickly integrated as a valued member to the permanently assigned military team at the embassy, especially when the tour of duty was extended to one year. ${ }^{51}$

This became important when the pro-Syrian Hezbollah-supported March 8 Alliance replaced the generally pro-U.S. March 14 Alliance government in June 2011. ${ }^{52}$ Calls in the U.S. Congress and even initial guidance from the Defense Department suggested terminating training with the Lebanese Armed Forces. ${ }^{53}$ Advising the ambassador to reject this position, the SOC-forward recommended that the United States retain these relationships. Withdrawing support would only concede influence to Hezbollah; by staying, the United States could still exert influence.

SOCCENT was also concerned that the Iranian Quds Force, a branch of Iran's Islamic Revolutionary Guards Corps that specializes in unconventional warfare and intelligence operations, ${ }^{54}$ would replace the U.S. training teams. To her credit, the ambassador took the recommendation and successfully fought off attempts to end the SOF mission.

The continued investment has paid dividends over the years. One such example was Lebanon's fight against the Islamic State. In 2017, an estimated 600 Islamic State fighters controlled roughly 120 square kilometers of Lebanese territory. On August 19, the Lebanese Armed Forces launched Operation Fajr al-Jur (Dawn of the Outskirts) to reclaim the territory. The operation was a resounding success and was regarded as "its most proficient [counterterrorism] operation since the end of the 1975-1990 civil war." 55

In less than two weeks, they had defeated the Islamic State fighters, expelling the defeated militants and their families from the country. It is doubtful they would have been so successful without the long-term TSOC campaign to build a capable Lebanese Armed Forces.

\section{Conclusion}

Today's TSOCs have come a long way since they were forced on the combatant commands in 1983. By 1986, for example, SOCSOUTH was down to only Seven of its authorized 23 personnel. But with the growth and expanding employment of SOF, by 2009, SOCCENT totaled more than 900 soldiers, sailors, airmen, marines, and civilians from the active and reserve components in either an assigned, attached, or temporary duty status - far beyond the 23 originally directed by the Joint Special Operations Agency back in $1983 .{ }^{56}$ The growth of the TSOC, however, should not be surprising given the explosive growth of SOF after $9 / 11$, from $\$ 3.7$ billion in $2001^{57}$ to $\$ 13.7$ billion in $2020 .^{58}$

Over the past several decades, SOF operations have grown not only in scale and scope but also in visibility. Earlier SOF operations, such as the Joint Planning and Assistance Teams in El Salvador or SOF support to the hostage recovery mission in Colombia in 2008, were smaller in scale and scope and less visible. But now SOF takes a much more active and visible role around the globe, from battling the Islamic State in Syria to Operation Enduring Freedom-Philippines in the Pacific. The TSOC remains a critical element in ensuring that SOF is properly employed to support U.S. policy objectives. 
In November 2020, as further evidence of SOF's growing role, Acting Secretary of Defense Christopher Miller ordered the assistant secretary of defense for special operations and low-intensity conflict, special operations' top civilian in the Pentagon, to report directly to him. In essence, this elevated him to the level of the service secretaries. Miller justified the change to "streamline information flow, enhance decisionmaking and more adaptively and adeptly support our commanders and their superb soldiers, sailors, airmen and Marines." ${ }^{59}$ Similar words could have been used 40 years ago to justify the establishment of the TSOCs.

\section{Notes}

1 Joint Chiefs of Staff, Doctrine of the Armed Forces of the United States, JP 1 (Washington, DC: Joint Chiefs of Staff, 2013), xvi.

2 Armed Forces, U.S.C. 10.

3 Joint Chiefs of Staff, Doctrine for the Armed Forces of the United States, JP 1 (Washington, DC: Joint Chiefs of Staff, 2017).

4 See, for example, Amy Crawford, “The Swamp Fox,” Smithsonian Magazine, June 30, 2007, www.smithsonianmag. com/history/the-swamp-fox-157330429/.

5 John F. Kennedy, “Inaugural Address of John F. Kennedy," January 20, 1961, https://avalon.law.yale.edu/20th_century/kennedy.asp.

6 "U.S. Army Special Operations Center of Excellence," SOC, accessed November 1, 2020, www.soc.mil/SWCS/ about.html.

7 John Friberg, "History of the 8th Special Forces Group," SOFREP, July 9, 2016, https://sofrep.com/ news/8th-special-forces/.

8 Liam Collins, "Military Innovation in War: The Criticality of the Senior Military Leader" (PhD diss., Princeton University, 2014), 122-125, http://arks.princeton.edu/ark:/88435/dsp01br86b3727.

9 Mark Bowden, “The Desert One Debacle," The Atlantic 297, no. 4 (2006): 62-77.

10 James R. Locher III, "Has It Worked?-The Goldwater-Nichols Reorganization Act," Naval War College Review 54, no. 4 (2001): 10.

11 Holloway Commission, Holloway Commission Report (1980), https://nsarchive2.gwu.edu/NSAEBB/NSAEBB63/ doc8.pdf.

12 William Kernan, “The Holloway Report: Did It Reflect All the Facts and Lessons Learned” (essay, U.S. Army War College, 1987), 3, https://apps.dtic.mil/dtic/tr/fulltext/u2/a182845.pdf.

13 Susan L. Marquis, Unconventional Warfare: Rebuilding U.S. Special Operations Forces (Washington, DC: Brookings, 1997), 79-84.

14 Ibid., 84-86.

15 "United States Invades Grenada," History, accessed November 29, 2018, www.history.com/this-day-in-history/ united-states-invades-grenada.

16 John H. Cushman Jr., "Pentagon Study Faults Planning on Grenada," New York Times, July 12, 1986, www.nytimes. com/1986/07/12/world/pentagon-study-faults-planning-on-grenada.html.

17 Kathleen J. McInnis, Goldwater-Nichols at 30: Defense Reform and Issues for Congress, CRS Report R44474 (Washington, DC: Congressional Research Service, 2016), 4.

18 James R. Locher III, Victory on the Potomac: The Goldwater-Nichols Act Unifies the Pentagon (College Station: Texas A\&M University Press, 2002), 158.

19 The Nunn-Cohen Amendment was a rider to the 1978 National Defense Authorization Act that amended the Goldwater-Nichols Act. See Marquis, Unconventional Warfare, 107-147.

20 Ibid., 162-163.

21 The Nunn-Cohen Amendment designated SOF as a new major fund program with its own appropriation executed by SOCOM, but the TSOC was not included. See Marquis, Unconventional Warfare, 144-147.

22 Andrew Feickert, U.S. Special Operations Forces (SOF): Background and Issues for Congress, CRS Report RS21048 (Washington, DC: Congressional Research Service, 2020), 2.

23 Ibid. Note that the services were still required to provide all non-special operations peculiar administrative and logistical support to the TSOC consistent with their requirement for all SOF, but SOCOM could now provide SOF-peculiar material, supplies, and services to the TSOCs that it previously could not. See 10 U.S.C. $\$ 167(\mathrm{f})$ and Department of Defense, Support of the Headquarters of Combatant Commanders and Subordinate Unified Commands, DOD Directive 5100.03 (Washington, DC: Department of Defense, 2017), www.esd.whs.mil/Portals/54/Documents/DD/issuances/dodd/510003p.pdf. 
24 Joint Chiefs of Staff, Doctrine for the Armed Forces of the United States; Joint Chiefs of Staff, Joint Operations, JP 3-0 (Washington, DC: Joint Chiefs of Staff, 2018).

25 Armed Forces, 10 U.S.C. $\$ 167$ Unified combatant command for Special Operations Forces.

26 Department of the Army, Special Operations, ADP 3-05 (Washington, DC: Department of the Army, 2019).

27 Joint Chiefs of Staff, Special Operations.

28 Ibid.

29 Ibid.

30 Marc Gonsalves et al., Out of Captivity: Surviving 1,967 Days in the Colombian Jungle (New York: HarperCollins, 2009), xiii-25; Chris Kraul, "Slain U.S. Pilot May Be Honored," Los Angeles Times, September 24, 2008, www. latimes.com/archives/la-xpm-2008-sep-24-fg-janis24-story.html.

31 Ibid.

32 Gonsalves et al., Out of Captivity, xv.

33 This information is based on the co-author's experience as SOCSOUTH commander from 2005-2008.

34 Ibid.

35 Ibid.

36 Ibid.

37 Ibid.

38 Brian Petit, Going Big by Getting Small: The Application of Operational Art by Special Operations in Phase Zero (Denver: Outskirts Press, 2013), 135.

39 Each of the five active duty Special Forces Groups "keeps a company-sized element on a heightened state of readiness to serve as a direct-action, crisis response force for their specific command region." See Matthew Cox, "Pentagon to Decide if It Still Needs Green Beret Crisis Response Forces," Military.com, March 11, 2020, www.military. com/daily-news/2020/03/11/pentagon-decide-if-it-still-needs-green-beret-crisis-response-forces.html.

40 Tim Padgett, “Colombia’s Stunning Hostage Rescue," Time Magazine, July 2, 2008, http://content.time.com/ time/world/article/0,8599,1819862,00.html.

41 This information is based on the co-author's experience as SOCSOUTH commander from 2005-2008.

42 Petit, Going Big, 135.

43 Ibid., 136.

44 “Syrian Troops Leave Lebanon After 29-Year Occupation," New York Times, April 26, 2005, www.nytimes. com/2005/04/26/international/middleeast/syrian-troops-leave-lebanon-after-29year-occupation.html.

45 Casey L. Addis, Lebanon: Background and U.S. Relations, CRS Report R40054 (Washington, DC: Congressional Research Service, 2011), 4.

46 Ibid., 12.

47 This information is based on the co-author's experience as SOCCENT commander from 2008-2011.

48 Robert F. Worth and Nada Bakri, "Hezbollah Seizes Swath of Beirut From U.S.-Backed Lebanon Government," New York Times, May 10, 2008, www.nytimes.com/2008/05/10/world/middleeast/10lebanon.html.

49 Department of Public Information, Security Council Calls for End to Hostilities Between Hizbollah, Israel, Unanimously Adopting Resolution 1701 (New York: United Nations, 2006).

50 Nada Bakri and Hassan Fattah, "Clash Pits Hezbollah Against Rule in Lebanon," New York Times, January 24, 2007, www.nytimes.com/2007/01/24/world/middleeast/24lebanon.html.

51 This information is based on the co-author's experience as SOCCENT commander from 2008-2011.

52 Rebecca A. Hopkins, Lebanon and the Uprising in Syria: Issue for Congress, CRS Report R42339 (Washington, DC: Congressional Research Service, 2012), 1.

53 This information is based on the co-author's experience as SOCCENT commander from 2008-2011.

54 Miriam Berger, "What Is Iran's Revolutionary Guard Corps That Soleimani Helped to Lead?" Washington Post, January 4, 2020, www.washingtonpost.com/world/2020/01/04/what-is-irans-revolutionary-guard-corpsthat-soleimani-helped-lead/.

55 Nicholas Blanford, "The Lebanese Armed Forces and Hezbollah's Competing Summer Offensives Against Sunni Militants," CTC Sentinel 10, no. 8 (2017): 27-32.

56 This information is based on the co-author's experience as SOCCENT commander from 2008-2011.

57 Edward Bruner et al., Special Operations Forces in Operation Enduring Freedom: Background and Issues for Congress, CRS Report RS21048 (Washington, DC: Congressional Research Service, 2001), 3.

58 Feickert, U.S. Special Operations Forces (SOF), 6.

59 Corey Dickstein, “Acting Defense Secretary Orders Top Special Ops Civilian to Report Directly to Him,” Stars and Stripes, November 18, 2020, www.stripes.com/news/us/acting-defense-secretary-orders-top-special-ops-civil ian-to-report-directly-to-him-1.652557. 